\title{
Quantitative Easing In Overcoming the Crisis: Criticism ofQeinthe Monetary System Of Capitalism
}

\author{
AangKunaifi $^{\mathrm{a} *}$, FadaliRahman $^{\mathrm{b}} *$, AbdRosyid $^{\mathrm{c}_{*}}$, Mansur $^{\mathrm{d}} *$ FitriaNurMasithoh $^{\mathrm{e}} *$, Zainurrafiqi $^{\mathrm{f}_{*}}$, \\ Rusdiyanto $^{\mathrm{g} *}$, ArifSyafi'urRochman ${ }^{\mathrm{h} *}$, NawangKalbuana ${ }^{\mathrm{i} *}$ \\ ${ }^{\mathrm{a}} \mathrm{PhD}$ Student of Universitas Islam Negeri Sunan Ampel Surabaya, **Institut Agama Islam Al-KhairatPamekasan, East Java, \\ Indonesia. \\ ${ }_{\mathrm{b}, \mathrm{c}^{*}}$ Institut Agama Islam Al-KhairatPamekasan, East Java, Indonesia. \\ $\mathrm{d} *$ Sekolah Tinggi Agama Islam MiftahulUlumPamekasan, East Java, Indonesia \\ ${ }^{e}$ *Institut Agama Islam UluwiyahMojokerto, East Java, Indonesia \\ ${ }^{f^{*}}$ Universitas Madura Indonesia, J1 Raya Panglegur No. Km 3.5, Panglegur, Tlanakan, City Pamekasan, East Java 69317 \\ Indonesia \\ *Faculty of Economics and Business, UniversitasAirlangga Indonesia, Jl. Airlangga No.4, Airlangga, Gubeng, Surabaya, East \\ Java 60286 Indonesia., \\ $\mathrm{g}, \mathrm{h} *$ Universitas Gresik Indonesia, Jl. Arif Rahman Hakim No.2B, Gresik, City Gresik, East Java 60111 Indonesia \\ ${ }^{i *}$ PoliteknikPenerbangan Indonesia Curug, Jl. Raya PLP Curug, SerdangWetan, Kec. Legok, Tangerang, Banten 15820 \\ Indonesia \\ Email:alakunaifi@gmail.com, \\ b fadalirahman@alkhairat.ac.id, ${ }^{\mathrm{c}}$ rosyid@ alkhairat.ac.id, ${ }^{\mathrm{d}}$ elcmansur@ gmail.com, ${ }^{\mathrm{e}}$ fitrianm14@ gmail.com, zainurrafiqi@unira.ac \\ .id, ${ }^{\mathrm{g}}$ rusdiyanto.se.m.ak-2017@feb.unair.ac.id, ${ }^{\mathrm{h}}$ arifsyafiur@gmail.com, ${ }^{\mathrm{i}}$ nawang.kalbuana@ppicurug.ac.id
}

Article History: Received: 10 November 2020; Revised 12 January 2021 Accepted: 27 January 2021; Published online: 5 April 2021

\begin{abstract}
This study aims to describe the form of Quantitative Easing applied by the Central Bank as well as qualitatively measure its benefits and excesses. To obtain a description and know the benefits and excesses in question, the research approach uses a qualitative approach by conducting a literature study of several facts and quantitative easing studies by Bank Indonesia and the Fed from various literature and media inductively relevant theories. This study's findings show that excesses can be detrimental to society, and countries that are shariah are harmful that should be avoided. This research is expected to encourage further research to determine the correlation of Quantitative Easing policy to the resolution of economic crisis and obtain alternative solutions by implementing the Islamic monetary system.

The impact of the covid-19 pandemic that continues to this day causes economic shock, the slowing flow of goods commodities, decreased production, and decreased purchasing power of the community. Various policy efforts are carried out through fiscal stimulus as well as support through monetary policy in the form of quantitative easing.
\end{abstract}

Keywords: Quantitative Easing, Crisis, Monetary System, Capitalism, Islam.

\section{Introduction}

The current turmoil in the world's economic uncertainty has busy the world's countries looking for solutions to stop the bleeding from the fatal financial crash. Countries in the world that mostly implement the economic system of usury-based capitalism and gambling seek to maintain a fragile system by doing patchwork. Various crisis rescue packages were also prepared to cover the system's depravity; they stretched with trillions of dollars in funds. However, when depravity is covered up, there are other ulcers. Can watch the economic and financial crisis continue to wreak havoc on the countries of capitalism.

Davies, (2010) revealed historical facts in 1996 in the book The History of Money from Ancient Times to Present Day, at least throughout the 20th century, there have been 20 major crises that hit many countries. This means that the financial crisis occurs every 5 years, resulting in suffering for hundreds of millions of humanities. The great crash hit New York's capital markets, and the great depression was caused by banking failures. Still fresh in our memory in 2010, the crisis is again engulfing the world, in Europe, especially as the kampium countries of capitalism. Greece, Spain, France, Germany, and America did not escape the epidemic of the financial and banking crisis, which was quite terrible. The impact was quite devastating; let's say one of the oldest and largest investment banks aged 158 years, Lehman Brothers, was declared bankrupt. Several giant companies such as MerrilLinch, Chrysler, Goldman Sachs Group, and Xerox Corp were forced to lay off thousands and even tens of thousands of employees (Ramin, 2020; Afrizal, 2017). 
The case of pandemic covid-19 that occurred since December 2019 until now has caused an alarming recession impact. 22 countries recorded serious re-acquisitions until August 2020, with economic growth contracting minus 42.9\% (Arina et al., 2019; Sembiring, 2016; Murdanoto et al., 1997). Bank Indonesia has injected liquidity or quantitative easing (QE) in the banking industry worth Rp 662.1 trillion until mid-September 2020. The QE is in the form of a policy of decreasing the Minimum Mandatory Giro (GWM) of around Rp 155 trillion and monetary expansion of around Rp 491.3 trillion (Mayzan, 2018; Simorangkir \& Adamanti, 2010). Observing various phenomena of monetary crisis with various causes, the author was motivated to conduct a study on the effectiveness of quantitative easing $(\mathrm{QE})$ as a strategy to overcome the crisis, excesses of quantitative easing (QE) policy, and Islamic view of quantitative easing (QE) policy.

\section{Literature Review}

Research on Quantitative Easing (hereinafter abbreviated as QE) has been conducted by many researchers, both qualitatively and quantitatively. Most of the research on the influence and impact on inflation and other macroeconomic instruments such as; interest rates, unemployment, and gross domestic product (Ajah et al., 2020; Diamond, 2020; Perillo \& Battiston, 2020; Ramkumar \& Bates, 2020; Taghizadeh-Hesary et al., 2020). Min-Ho Nam concluded from his quantitative research that quantitative easing (QE) policies in developed countries such as the United States, Japan, Europe, and the United Kingdom have effectively helped lower inflation through the exchange rate channel, while if using trade channels the influence on inflation is insignificant (Bartkiewicz, 2020; Blattner \& Joyce, 2020; De Santis \& Holm-Hadulla, 2020; Tanaka, 2020; Ward, 2020). Other research shows that QE policy by the Fed has a significant influence on the financial sector in Indonesia (Pastpipatkul et al., 2015;Teguh\&Andaiyani, 2019; Rizky, 2015). This means that QE policy has an impact on monetary contraction in Indonesia, especially on interest rates and inflation. Quantitative easing (QE) policies by central banks such as currencies always have a positive and negative impact. Some researchers are also encouraged to know whether quantitative easing (QE) has a positive impact on macroeconomic conditions, especially in overcoming the crisis. Salman Sakir obtained the results of his quantifiable research that quantitative easing (QE) has a positive impact on GDP and unemployment rates, but has a negated impact on prices and liability burdens (Basri, 2017; Sakir, 2015; Morgan, 2011).

While in the research field of crisis management Islamic perspective or using islamic economic approach dominated by the offer of the use of gold-based currencies, the elimination of ribawi systems and derivative transactions, to the idea of the implementation of the economic system as a whole (Huda, 2017; Sumarni, 2020;Risal, 2019;Kunaifi, 2018; Saputra et al., 2021). The assumptions and arguments of the average researcher are constructed by the basics of the law and historical facts. Shabri revealed the findings of his qualitative research on monetary policy of capitalism to overcome the economic crisis through sub-prime-mortgage (quantitative easing distribution channel (QE) through the exchange rate channel is a policy that does not have an impact aka no income, no job, no asset(Adam, 2020;Majid, 2015; Fauzia, 2015) offers a solution back to gold and silver as the standard of monetary eyes, as it proved effective in stabilizing monetary and fiscal as long as the Islamic state existed, especially at the beginning of Islamic rule (Afriyenis, 2016; Amri, 2018; Jaelani, 2018). In fact, the offer of implementing the Islamic monetary and economic system is very relevant to restore the financial health of crisis-sized European countries such as Greece and Spain, namely abolishing the system of usury, gambling, and cheating (Zainudin, 2015; Hartono, 2011; Murfi et al., 2020; Ma'mun, 2019).

A summary of some research on $\mathrm{QE}$ policy, the effect of $\mathrm{QE}$ policy on crisis management, and Islamic solutions to crisis management can be summarized as follows:

Table 1: Literature Review OnQuantitaive Easing Policy and Crisis Handling of Islamic Economic Perspectives

\begin{tabular}{|c|c|c|c|c|c|}
\hline No & $\begin{array}{l}\text { Researcher, } \\
\text { Year }\end{array}$ & Title & Goal & Method & Findings \\
\hline 1 & $\begin{array}{l}\text { Min-Ho Nam, } \\
2018\end{array}$ & $\begin{array}{l}\text { The Effect of } \\
\text { Quantitative } \\
\text { Easing on Inflation } \\
\text { in Korea }\end{array}$ & $\begin{array}{l}\text { Evaluating the impact } \\
\text { of quantitative easing } \\
\text { (QE) on inflation in } \\
\text { Korea on quantitative } \\
\text { easing (QE) at the US } \\
\text { Central Bank, Europe, } \\
\text { the UK and Japan }\end{array}$ & $\begin{array}{l}\text { Quantitative } \\
\text { analysis of } \\
\text { VAR-X }\end{array}$ & $\begin{array}{l}\text { Spillover due to } \\
\text { quantitative easing (QE) } \\
\text { puts downward pressure } \\
\text { on inflation in Korea } \\
\text { through value exchange } \\
\text { channels } \\
\text { (currencies/money } \\
\text { markets) } \\
\text { Spillover quantitative } \\
\text { easing (QE) has no } \\
\text { significant effect if } \\
\text { through trade channels }\end{array}$ \\
\hline
\end{tabular}




\begin{tabular}{|c|c|c|c|c|c|}
\hline No & $\begin{array}{c}\text { Researcher, } \\
\text { Year }\end{array}$ & Title & Goal & Method & Findings \\
\hline 2 & $\begin{array}{l}\text { Muhammad } \\
\text { Teguh\& Sri } \\
\text { Andaiyani, } \\
2019\end{array}$ & $\begin{array}{l}\text { The US } \\
\text { Quantitative } \\
\text { Easing and } \\
\text { Indonenesia } \\
\text { Financial Market. } \\
\text { Does It Matter? }\end{array}$ & $\begin{array}{l}\text { Analyzing the impact } \\
\text { of quantitative easing } \\
\text { (QE) policy by the Fed } \\
\text { on the financial sector } \\
\text { in Indonesia }\end{array}$ & $\begin{array}{l}\text { Quantitative, } \\
\text { using Vector } \\
\text { Auto } \\
\text { Regression } \\
\text { analysis }\end{array}$ & $\begin{array}{l}\text { There is a significant } \\
\text { influence of quantitative } \\
\text { easing (QE) policy by } \\
\text { the Fed on the financial } \\
\text { sector in Indonesia }\end{array}$ \\
\hline 3 & $\begin{array}{l}\text { Salman Sakir, } \\
2015\end{array}$ & $\begin{array}{l}\text { Does Quantitative } \\
\text { Easing Work? }\end{array}$ & $\begin{array}{l}\text { Explore the impact of } \\
\text { quantitative easing } \\
\text { (QE) on the economy in } \\
\text { the United States }\end{array}$ & $\begin{array}{l}\text { Qualitative, } \\
\text { through } \\
\text { quantitative } \\
\text { easing (QE) } \\
\text { data review } \\
\text { from } 2002 \\
\text { to } 2014\end{array}$ & $\begin{array}{l}\text { Impact in U.S. } \\
\text { macroeconomics: } \\
\text { 1) Asset increase } \\
\text { 2) Increased liabilities } \\
\text { 3) Increase in GDP } \\
\text { 4) Increase in } \\
\text { production factor price } \\
\text { 5) Loan Interest } \\
\text { Decrease } \\
\text { 6) Decrease in } \\
\text { Unemployment }\end{array}$ \\
\hline 4 & $\begin{array}{l}\text { HoirulAmri, } \\
2018\end{array}$ & $\begin{array}{l}\text { Analysis of } \\
\text { Monetary Policy at } \\
\text { the Beginning of } \\
\text { Islamic } \\
\text { Government on } \\
\text { Islamic Economic } \\
\text { Development }\end{array}$ & $\begin{array}{l}\text { Application of Islamic } \\
\text { monetary policy in } \\
\text { development }\end{array}$ & $\begin{array}{l}\text { Literature } \\
\text { review, } \\
\text { historical } \\
\text { facts }\end{array}$ & $\begin{array}{l}\text { The effectiveness of the } \\
\text { islamic state's initial } \\
\text { government monetary } \\
\text { policy with indications } \\
\text { of rising aggregator } \\
\text { demand and aggregate } \\
\text { supply }\end{array}$ \\
\hline 5 & $\begin{array}{l}\text { DjokoSetyo } \\
\text { Hartono, } \\
2011\end{array}$ & $\begin{array}{l}\text { Islamic Economy } \\
\text { as An Alternative } \\
\text { Solution to the } \\
\text { European } \\
\text { Economic Crisis }\end{array}$ & $\begin{array}{l}\text { Proving funding from } \\
\text { Europe Central Bank } \\
\text { and IMF ineffective } \\
\text { against handling crisis } \\
\text { in Europe }\end{array}$ & $\begin{array}{l}\text { Literature } \\
\text { review and } \\
\text { news 2008- } \\
2010\end{array}$ & $\begin{array}{l}\text { The ineffectiveness of } \\
\text { the monetary system in } \\
\text { the economy of } \\
\text { capitalism, shows } \\
\text { indications of the need } \\
\text { for an alternative } \\
\text { monetary policy } \\
\text { strategy, namely the } \\
\text { Islamic monetary } \\
\text { system }\end{array}$ \\
\hline 6 & $\begin{array}{l}\text { M. } \\
\text { ShabridanAbd. } \\
\text { Majid, } 2015\end{array}$ & $\begin{array}{l}\text { Economic Crisis } \\
\text { and Its Solution in } \\
\text { an Islamic } \\
\text { Perspective: } \\
\text { Analysis of the } \\
\text { Global Economic } \\
\text { Crisis }\end{array}$ & $\begin{array}{l}\text { Describing the causes } \\
\text { of the } 2008 \text { crisis in the } \\
\text { USA and their solutions } \\
\text { in an Islamic } \\
\text { perspective }\end{array}$ & $\begin{array}{l}\text { Qualitative: } \\
\text { Literature } \\
\text { review funds } \\
\text { empirical } \\
\text { data }\end{array}$ & $\begin{array}{l}\text { Crisis management fund } \\
\text { assistance in the form of } \\
\text { sub prime mortgage } \\
\text { ineffective, no income, } \\
\text { no job, no asset. Donor } \\
\text { countries are likely to } \\
\text { default }\end{array}$ \\
\hline
\end{tabular}

Based on table 1, it can be concluded that the study of quantitative easing (QE) in crisis management is a strategy based on established theories and becomes the main avenue in the economy of capitalism. But no applicative solution has been provided of the effectiveness of the strategy in handling the crisis, while the Islamic economic perspective has not been combined in becoming a blended strategy that will be a concrete pattern of islamic monetary system. The position of research and novelty in this article can be explained through the following table:

Table 2: Research Position and Novelty

\begin{tabular}{|c|c|c|c|c|}
\hline Variable & Year & Method & Goal & Findings \\
\hline $\begin{array}{l}\text { Quantitative } \\
\text { Easing dalam } \\
\text { Penanganan } \\
\text { Krisis }\end{array}$ & 2020 & $\begin{array}{l}\text { Facilitative: } \\
\text { literature review } \\
\text { and empirical } \\
\text { data }\end{array}$ & $\begin{array}{l}\text { Knowing the study of } \\
\text { the law based on the } \\
\text { opinion of Muslim } \\
\text { economists }\end{array}$ & $\begin{array}{l}\text { 1. Quantitative easing (QE) is a policy } \\
\text { based on monetary market law } \\
\text { (supply \&demand) } \\
\text { 2. Quantitative easing (QE) is part of } \\
\text { monetary strategy and policy. } \\
\text { Legally fiqh with the condition } \\
\text { controlled by the government to }\end{array}$ \\
\hline
\end{tabular}




\begin{tabular}{|c|c|c|c|}
\hline Variable & Method & Goal & Findings \\
\hline & & & $\begin{array}{l}\text { stimulate the real sector } \\
\text { Quantitative easing (QE) will } \\
\text { effectively overcome the crisis if } \\
\text { using real sector channels as well as } \\
\text { subsidies for affected communities } \\
\text { and improvement of public facilities }\end{array}$ \\
\hline Novelty & Yes & No & No. 2 and 3 \\
\hline Position & As complementary & & \\
\hline
\end{tabular}

\section{Methodology}

This study uses literature study method, namely data collection through secondary data sourced from the Central Bank, articles, and news in print and electronic media (Juanamasta et al., 2019; Prabowo et al., 2020; Rusdiyanto, Agustia, et al., 2020; Rusdiyanto, Hidayat, et al., 2020; Syafii et al., 2020), (Juanamasta et al., 2019), (R. Rusdiyanto \& Narsa, 2019), (Gazali, Kusuma, Aina, Bustaram, Amar, et al., 2020), (Syafii et al., 2020), (Lamtiar et al., 2021), (Gazali, Kusuma, Aina, Bustaram, Risal, et al., 2020), (Rusdiyanto, Sawarjuwono, et al., 2020), (Shabbir et al., 2021), (Susanto et al., 2021), (Luwihono et al., 2021), (Rahayu et al., 2020), (Utari et al., 2020), (Prabowo et al., 2020), (Astanto et al., 2020), (H. T. Rusdiyanto et al., 2020), (Rusdiyanto, Sawarjuwono, et al., 2020), (HIDAYAT et al., 2020), (Rusdiyanto \& Narsa, 2020), (Ulum et al., 2020), (R. Rusdiyanto et al., 2019), (Hidayat et al., 2020), (Zainurrafiqi et al., 2020), (Zainurrafiqi et al., 2020), (Hadi Susanto et al., 2021), (Woro Utari et al., 2020), (Susanto et al., 2021). The data and information are processed by the classification stage of the source and content of the news and the calsterization of the year of publication. Furthermore, it is summarized to get relevant important points regarding its effectiveness in resolving the crisis and its excesses in the monetary spectrum.

The summary obtained is then analyzed and reviewed based on relevant monetary theories and discussed based on the study of Islamic law (fiqh and fiqh rules). The result of the discussion is a form of criticism of quantitative easing (QE) policy in the monetary system as well as an alternative concept in the Islamic spectrum.

\section{Discussion}

\subsection{Implementation Of Quantitative Easing (Qe)}

Quantitative Easing (hereinafter abbreviated as QE) is a policy in the monetary field to increase the quantity of offers of kartal money and giral money (M1 and M2). Through this policy, it is expected that there will be a stimulus of people's economic activities. Quantitative easing (QE) policy is used to overcome recessions or economic crises caused by events such as natural disasters, pandemics, wars, or political tragedies in a country (Cochrane, 2020; Dutkowsky \& VanHoose, 2020; Evgenidis \& Papadamou, 2020; Marios et al., 2020; Masoud et al., 2020).

In United States, for example, the Fed often uses expansive monetary policy as a policy response to counter economic crises. The quantitative easing (QE) policy used by the Federal Reserve in the form of buying U.S. government bonds and mortgage-based securities issued by government-sponsored companies such as Fannie Mae and Freddie Mac. Quantitative easing (QE) program conducted as intended occurred in 2008 and ended in 2014. During these three phases, the Federal Reserve purchased $\$ 4.48$ trillion worth of financial assets that boosted the money supply in the U.S. economy (Chapman \& Kulkarni, 2020; Dinh et al., 2020; Fiebiger \& Lavoie, 2020; Schlepper et al., 2020; Todorov, 2020;Sakir, 2015). Factually the policy uses three channels, among others (Kaminska \& Zinna, 2020; Luck \& Zimmermann, 2020; Yang et al., 2020; Zabala \& Prats, 2020; Nam, 2018): Exchange Rate Channel, Trade Channel, Portofolio

In Indonesia, during the covid-19 pandemic, Bank Indonesia conducted monetary policy measures in the form of quantitative easing (QE) with channels such as (Sihono \& Yusof, 2012; Bank Indonesia, 2020): Purchase of Government Securities, Banking Term-Repos, FX Swap, Decrease and temporary elimination of Minimum Mandatory Giro (GWM). In principle, $\mathrm{QE}$ is a monetary policy to increase the amount of money circulating in the community, both M1 and M2 which is intended to provide stimulus for economic activities in the community. This policy is carried out in line with the theory of demand for money, where the demand for money (M1 and M2) is directly proportional to the price, quantity of goods, and volume of transactions. That is, to increase the volume of transactions or public consumption must be supported by the amount of money circulating in the community. The increase in the amount of money is done through government capital expenditures as well as the ease of the public in obtaining credit. 


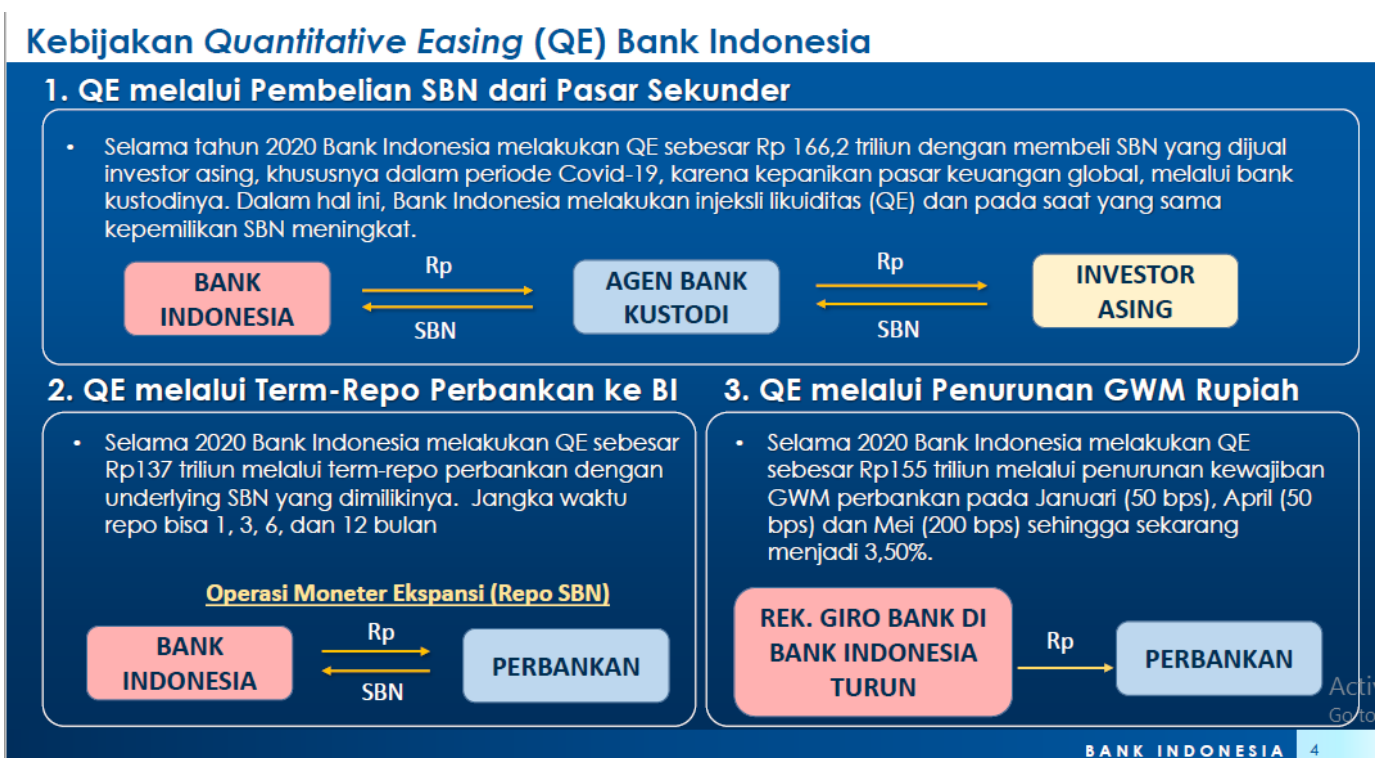

Figure 1: Graphics of QE Implementation by Bank Indonesia

Based on figure 1 above, it can be concluded that the quantitative easing (QE) policy distribution channel is mostly on the echange rate channel, so banks and investment instruments are spillover to be channeled in the form of credit to the community. The impact is an increase in banking assets, a reduction in interest rates, and an insignificant reduction in unemployment, assuming the use of spillover credit for entrepreneurship or business development.

\subsection{Milton Friedman Perspective Qe Study}

Friedman, 2009; Hasoloan, (2014) is a monetary economist who emphasizes the importance of money stocks and people's income expectations in increasing consumption and economic activity. Expertise (Milton Friedman, 2009) in economics no one doubts. He is said to be the second most influential man in economic history after Adam Smith. Others say, after John Maynard Keynes, no more economists are able to change the way of thinking and how to use other tools of economics (Milton Friedman, 2009). At its peak, in 1976, he was awarded the Nobel Prize in Economics from the Swedish government (Milton Friedman, 2009).

Friedman, (2009) concerning money and monetary policy as important elements of economic activity. The theory is formulated quantitatively in the equation: $\mathrm{MV}=\mathrm{PQ}$. The amount of money that must exist (M) with its release time multiplier (V) is equivalent to the economic output i.e. the total number of transactions (PxQ). The speed at which money is circulated depends on economic factors such as interest rates and inflation forecasts. In addition, Friedman suggests that rather than storing goods people would rather hold money for other reasons, namely because of security or because they think that the price of the property and the price of other assets may be going down. But friedman's empirical study found that these economic factors have little impact on the economy and that their impact tends to decline over time. He also concluded that the pace of money is relatively stable, so that the amount of money is mainly impacting the level of economic activity (Milton Friedman, 2009).

Sluggish monetary policy, particularly in anticipation of slowing transactions in the community, is largely due to variable delays or inaction in anticipation of changes in money supply. Although this theory of demand for money is in line with the classical philosophy of theory that assumes that the state of the economy is always in full employment, the difference is that Friedman does not believe the policy is done liberally as classical economists think, but is directly controlled by the government (An-Nawawi, 2015).

Based on the quantitative formulation of the demand for money formulated by Friedman, it can be concluded that the availability of money is an inevitability as a representation of wealth that can be used by people to meet their needs. Such inevitability must be accurately measured to avoid permanent inflantion. Since inflation is a monetary phenomenon, the only solution to the problem of inflation is to control the growth of money supply. (Michael Friedman, 2014) explained that monetary authorities could have created depression, inflation and uninded economic outcomes through their mistakes in managing money supplies.

The empirical facts of the economic crisis in the United States in 1998, 2008, 2014, and 2020 show the vulnerability of the monetary system of capitalism. Orientation to the interests of capitalists resulted in weakening 
monetary control by the government so that the spillover quantitative easing (QE) is widely utilized by capital owners, especially financial or banking businesses. The financial sector and its derivatives transactions generate accumulation among the have, so the thrust to aggregate consumption and production is also low. In contrast to the Chinese economy that since 2011 began to lead in the global economy, especially in the investment and trade sectors of the real sector. In 2011 China's trade reached $70 \%$ of GDP, even the largest money holder in the world with a value of more than USD 2.5 trillion. Such conditions are the basis that China will be the Strongest Challenger of the United States in the economic field (Lee et al., 2011; Zakaria, 2011). High investment and trade will automatically increase entrepreneurship, which will bring rapid economic growth and opportunities at various levels.

\subsection{Qe Study OfUmerChapra Perspective}

(Chapra, 2016) is an Islamic economic figure who has the idea of creating a new system in the economy. The destruction of the socialist economic system and the injustice of the economic hegemony of capitalism became the basis for the idea. The liberal-patterned economy applied in the Islamic world has created economic injustices, a ribawi banking system, and the dominance of unfair market mechanisms (Manan \& SH, 2017;Waluyo, 2018; Husaini \& Hidayat, 2002;Al-Kaf, 2009). The new system in economics is offered through scientific works such as: Towards a just monetary system, Islam and the economic challenge, Islam and economic development, the future of economics; an Islamic perspective.

But as a mainstream Islamic economic figure as classified by (Adiwarman, 2010) in his book Islamic Micro Economy. This madzab axis recognizes the classic economist's opinion that economic problems lie in limited natural resources. (Chapra, 2016) itself argues that efforts to develop an Islamic economy should not be by rejecting and destroying the results of the analysis that has been achieved by conventional economists his opinion on the monetary system is actually not much different from the opinions of classical and neo-classical economists such as Irving Fisher, and Keynes (Milton Friedman, 2009). In general, the theory of demand for money initiated by conventional economists can be accepted with a certain note. (Chapra, 2016) argues that economic growth will be optimal at a time when resource allocation does not fall on black market forces.

The growth of M1 and M2 should be carried out by central banks in a measurable manner through rules that can guarantee the availability and growth of healthy money supply. It is factually acknowledged by UmerChapra that monetary policy is often not well run or organized (Chapra, 2000;Chapra, 2000). Supplay money according to him can be managed prerogeratively by the government by financing projects of social interests, provision of housing, health facilities, and education for the poor (Iwata, 1996). Based on this opinion, it can be understood that supplay or quantitative easing is necessary, both through the central bank as a monetary policy stakeholder and the government as a fiscal policy stakeholder.

Dengan demikian kebijakan quantitative easing (QE) merupakan strategi dan kebijakan moneter yang dapat diterima dalam khazanah ekonomi Islam, dengan catatan terorganisasi dengan baik, tetap menjaga stabilitas nilai mata uang, dan pengembangan yang tidak berlebihan. Hal itu sejalan dengan pendapat Milton Friedman sebagai pakar moneter konvensional, masing-masing dengan argumentasi kondisional sebagai persyaratangunamencapaikebijaka quantitative easing (QE) yang benar-benar efektif.

\subsubsection{Analysis}

Analysis of the effectiveness of quantitative easing (QE) in overcoming monetary crisis and recession due to pandemic can be followed as follows:

a. The purpose of quantitative easing (QE) is to provide M1 and M2 to stimulate markets and economic activities; Friedman's quantitative formulation in terms of the relationship of the amount of money in circulation with the volume of transactions in a straight line can be accepted by Islamic economists from both mainstream madzab and critical madzab, this is evidenced by the absence of a comparison formulation of the Islamic version. The theory of demand and supply of money only gets criticism in aspects of the function of money as a commodity that is absolutely unacceptable for 3 reasons, among others: it has no intrinsic utility, has no difference in quality, and does not have a specific identity. While the source of monetary expansion islamic economic perspective there are 3 namely: fiat money creation, credit money, balance of payments surplus(Cochrane, 2020; Muhammad, 2018).

b. Market mechanism assumptions state that M1 and M2 supply can have a direct impact on inflation; M1 and M2 supplay through quantitative easing (QE) have a direct impact on inflation. This is proven and recognized based on empirical data, for example during the crisis of 2008 to 2014 that occurred in the USA and Korea as Min-Ho Nam research:

The study's empirical results reveal that all QEs put additional downward pressure on Korea's inflation through currency appreciation. On the other hand, QE transfer via a trade channel has proved ineffective in 
enhancing aggregate demand in EMEs. Just those of the Fed and the European Central Bank are estimated to be important compared to the inflation impacts of individual QE programs in Korea. With respect to the robustness of empirical results, an alternative estimate using long-term interest rates as an alternative indicator for $Q E$ rather than security bearings remains consistent with the basic results (Aghajanzadeh \& Therkelsen, 2019; Fehrer et al., 2018; Speckesser et al., 2019; Wentrup et al., 2019; Whalen, 2019;Nam, 2018).

c. Quantitative easing $(\mathrm{QE})$ as a whole puts additional downward pressure on inflation in Korea through appreciation of the value of the currency. It is also a major criticism of madzab's critical economist, Jamal Harwood who argues that during the 4 years of quantitative easing (QE) policy in the USA did not fix anything, except for the pseudo-unemployment decline, but inflation soared. The policy is to print more and more money from nothing Financial sector economic analysts (JP Morgan and Credit Suisse) London, United Kingdom, (Ajah et al., 2020; Diamond, 2020; Perillo \& Battiston, 2020; Ramkumar \& Bates, 2020; Taghizadeh-Hesary et al., 2020).

This potential inflansi is also diwarning by Friedman, where the supply of money is not only handed over to the Central Bank. Since inflation according to Friedman is merely a monetary phenomenon, the only solution to the problem of inflation is to control the growth of money supplies. So the money supply included in the form of quantitative easing $(\mathrm{QE})$ should pay attention to the real sector, namely the value or volume of transactions (PQ). Meanwhile, Chapra provides solutions on the government's direct involvement in quantitative easing (QE) to increase purchasing power $(\mathrm{PQ})$ through appropriate direct subsidies in the sector of basic needs, public facilities, health, and education (Bartkiewicz, 2020; Blattner \& Joyce, 2020; De Santis \& Holm-Hadulla, 2020; Tanaka, 2020; Ward, 2020).

d. The impact of quantitative easing (QE) implementation for the case of recisisi or crisis due to pandemic with the result of the financial crisis (capital market and money market) has different characteristics. Kritik (Rizky, 2015; Jamal Harwood, Chacha, 2017) on quantitative easing (QE) especially conducted by the Fed during the period 2008 to 2014 as follows:

1) Quantitative easing (QE) has no relation to unemployment or economic stimulus. Money goes to banks that feel the need to rebuild their sharply slumped balance sheets. The disbursed money is like a drop of water on the stock market to stay afloat, and is used through a "protection team" to keep the US gold price (in dollars) low - short selling in the gold and silver markets aggressively to maintain the upper limit of the only real monetary alternative to the dollar.

2) As for keeping the balance sheet balanced, the Fed is buying new U.S. bonds issued to finance a large U.S. government current budget deficit that reaches $\$ 700$ billion annually, which is lower than the last few years of $\$ 1.200$ billion annually. So, in this case quantitative easing (QE) is very important because foreign governments especially China and Japan no longer want to buy U.S. bonds. The U.S. is currently experiencing an increasing budget deficit and declining demand for the dollar. Therefore, the Fed scored the dollar while trying to stay confident to convey to the world that the economy is improving (The Collapse of Global Capitalism: What Can We Learn from the Global Financial Crisis?

3) Quantitative easing (QE) is seen as a financial crime committed by capital owners, especially those involved in the money market, capital markets, and various derivatives transactions systematically. But it should be distinguished the case of the 2008 crisis as a pure financial crisis that only occurred in the financial business sector and in no way hit businesses that move in the real sector purely.

e. Recession and crisis that occurred in 2020 due to pandemic is purely weakening commodity circulation in all real sectors. Therefore, the impact is really crippling the economic activities of the community due to the weakening of monetary flow to the community. In the pandemic recession, money in both subsidies and cash assistance, and other instruments significantly affected the economy. Through the stimulus channeled appropriately able to deliver Indonesia from the brink of crisis, this is proven by the contraction of Indonesia's economic growth only $2.7 \%$ much better than other countries.

Based on the analysis above quantitative easing (QE) policy is a real effective weapon in overcoming the economic crisis with ideal conditions as explained Milton Friedman, UmerChapra, and Jamal Harwood. According to (T. L. Friedman, 2000) the United States with its capitalist economy is able to americanize parts of the world as a form of world recognition of the high growth and expansion of its products (Beauchamp \& Thomas, 2009; Thomas L, 2009; Crosling et al., 2009) the Islamic economy can also be used as the focus of the world through the application of the Islamic monetary and fiscal system. 


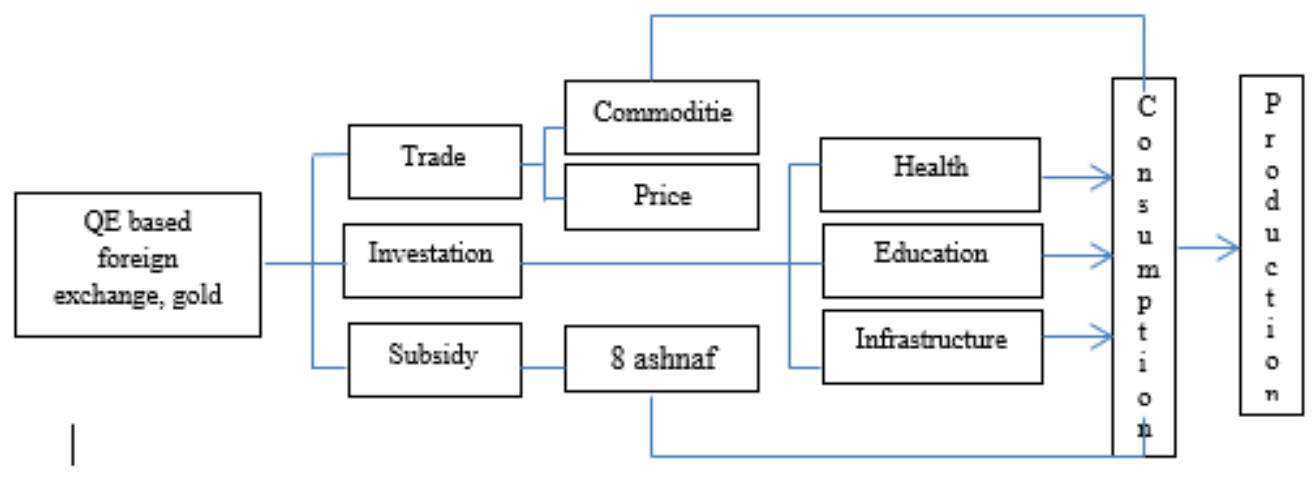

Figure 2: Islamic Monetary Economics in Overcoming the Crisis Through Quantitative Easing

In figure 2, the quantitative easing (QE) policy spilloverchanneled through commodity trading, investment, and subsidies will drive and increase consumption. Increased consumption has an impact on the occurrence of temporary inflation that can be overcome by increased production. Increasing the purchasing power of the community will increase entrepreneurial activities, increase labor absorption, and increase state revenues in the form of zakat, infak, shadaqah, waqf, kharaj, jizyah, and usyur.

\section{Conclusion}

Quantitative demand theory of money is still effective to be used as a basis in solving economic problems, especially in the monetary policy sector. Quantitative easing (QE) policy is an instrument in stabilizing the availability of money and transaction volume in the community. Quantitative easing (QE) policy has the potential to create high inflation if it is not well organized or controlled, i.e. there is no motive element of financial crime. Quantitative easing (QE) policy through trade channels and subsidies and consumption of public facilities can be said to be effective in crisis situations due to pandemic

\section{References}

Adam, M. (2020). Paradigma Keuangan Islam dalam Menghadapi Krisis. Al-Mashrafiyah: JurnalEkonomi, Keuangan, Dan Perbankan Syariah, 4(1), 46-57.

Adiwarman, K. (2010). Ekonomi Mikro Islami. Rajawali.

Afriyenis, W. (2016). Perspektif Ekonomi Islam Terhadap Utang Luar Negeri Pemerintah dalam Pembangunan Ekonomi Indonesia. Maqdis: JurnalKajianEkonomi Islam, 1(1), 1-16.

Afrizal, R. (2017). Etika bisnis islamperspektifmuhammaddjakfar. Universitas Islam Negeri Sumatera Utara.

Aghajanzadeh, A., \&Therkelsen, P. (2019). Agricultural demand response for decarbonizing the electricity grid. Journal of Cleaner Production, 220, 827-835. https://doi.org/10.1016/j.jclepro.2019.02.207

Ajah, B. O., Uwakwe, E. E., Nwokeoma, B. N., Ugwuoke, C. O., \& Nnamani, R. G. (2020). Ameliorating the plight of awaiting-trial inmates in Ebonyi State, Nigeria through reasonable bail conditions. Pertanika Journal of Social Sciences and Humanities, 28(4), 2897-2911. https://doi.org/10.47836/PJSSH.28.4.22

Al-Kaf, H. (2009). PerspektifEpistemologisTeologi Islam Liberal. Ulumuna, 13(2), 305-332.

An-Nawawi, I. (2015). RiyadhusShalihin. Pustaka Al-Kautsar.

Arina, C. A., Amir, D., Siregar, Y., \& Sembiring, R. J. (2019). The role of polymorphism gen methylene tetra hydrofolatereductase (MTHFR) C677T in ischaemic stroke patients with and without hypertension. Open Access Macedonian Journal of Medical Sciences, 7(1), 29.

Astanto, D., Rusdiyanto, M. F., Khadijah, S. N., Rochman, A. S., \& Ilham, R. (2020). MACROECONOMIC IMPACT ON SHARE PRICES: EVIDENCE FROM INDONESIA. Solid State Technology, 63(6), 646-660.

Bartkiewicz, P. (2020). Quantitative easing: New normal or emergency measure? Contemporary Economics, 14(3), 306-319. https://doi.org/10.5709/ce.1897-9254.406

Basri, M. C. (2017). India and Indonesia: Lessons learned from the 2013 taper tantrum. Bulletin of Indonesian Economic Studies, 53(2), 137-160.

Beauchamp, C., \& Thomas, L. (2009). Understanding teacher identity: An overview of issues in the literature and implications for teacher education. Cambridge Journal of Education, 39(2), 175-189.

Blattner, T. S., \& Joyce, M. A. S. (2020). The Euro Area Bond Free Float and the Implications for QE. Journal of Money, Credit and Banking, 52(6), 1361-1395. https://doi.org/10.1111/jmcb.12685

Chacha, T. (2017). The effect of FED's quantitative easing policy on listed companies and sectors in South Africa. University of Cape Town.

Chapman, G. O., \& Kulkarni, K. G. (2020). Comparison of Monetary Policy Actions: UK, Japan, and USA during the Financial Crisis of 2008. SCMS Journal of Indian Management, 17(1), 5-15. 
https://www.scopus.com/inward/record.uri?eid=2-s2.0-

85090728820\&partnerID=40\&md5=29da1230b8daf4bb6490c8c37dcd44d3

Chapra, M. U. (2000). Is it necessary to have Islamic economics? The Journal of Socio-Economics, 29(1), 21-37.

Chapra, M. U. (2016). The future of economics: An Islamic perspective (Vol. 21). Kube Publishing Ltd.

Cochrane, J. H. (2020). Strategic review and beyond: Rethinking monetary policy and independence. Federal Reserve Bank of St. Louis Review, 102(2), 99-119. https://doi.org/10.20955/r.102.99-119

Crosling, G., Heagney, M., \& Thomas, L. (2009). Improving student retention in higher education: Improving teaching and learning. Australian Universities' Review, The, 51(2), 9-18.

Davies, G. (2010). History of money. University of Wales Press.

De Santis, R. A., \& Holm-Hadulla, F. (2020). Flow Effects of Central Bank Asset Purchases on Sovereign Bond Prices: Evidence from a Natural Experiment. Journal of Money, Credit and Banking, 52(6), 1467-1491. https://doi.org/10.1111/jmcb. 12665

Diamond, W. (2020). Safety Transformation and the Structure of the Financial System. Journal of Finance, 75(6), 2973-3012. https://doi.org/10.1111/jofi.12967

Dinh, T. N., Kuo, K.-C., Lu, W.-M., \& Nguyen, D. T. (2020). The effect of quantitative easing on Asian construction firms' performance. International Journal of Construction Management. https://doi.org/10.1080/15623599.2020.1846887

Dutkowsky, D. H., \&VanHoose, D. D. (2020). Equal treatment under the Fed: Interest on reserves, the federal funds rate, and the 'Third Regime' of bank behavior. Journal of Economics and Business, 107. https://doi.org/10.1016/j.jeconbus.2019.105860

Evgenidis, A., \&Papadamou, S. (2020). The impact of unconventional monetary policy in the euro area. Structural and scenario analysis from a Bayesian VAR. International Journal of Finance and Economics. https://doi.org/10.1002/ijfe.2088

Fauzia, I. Y. (2015). Mendeteksi Kebangkrutan Secara Dini Perspektif Ekonomi Islam. EKUITAS (Jurnal Ekonomi Dan Keuangan), 19(1), 90-109.

Fehrer, J. A., Benoit, S., Aksoy, L., Baker, T. L., Bell, S. J., Brodie, R. J., \&Marimuthu, M. (2018). Future scenarios of the collaborative economy: Centrally orchestrated, social bubbles or decentralized autonomous? Journal of Service Management, 29(5), 859-882. https://doi.org/10.1108/JOSM-04-2018-0118

Fiebiger, B., \& Lavoie, M. (2020). Helicopter Ben, Monetarism, The New Keynesian Credit View and Loanable Funds. Journal of Economic Issues, 54(1), 77-96. https://doi.org/10.1080/00213624.2020.1720567

Friedman, Michael. (2014). Foundations of space-time theories: Relativistic physics and philosophy of science (Vol. 113). Princeton university press.

Friedman, Milton. (2009). Milton Friedman.

Friedman, T. L. (2000). The Lexus and the olive tree: Understanding globalization. Farrar, Straus and Giroux.

Gazali, Kusuma, A., Aina, M., Bustaram, I., Amar, S. S., Rusdiyanto, Tjaraka, H., \&Panjilaksana, S. D. D. (2020). The Effect of Financial Performance on Stock Prices: a Case Study of Indonesian. Talent Development and Excellence, 12(1), 40074016. http://iratde.com/index.php/jtde/article/view/1351

Gazali, Kusuma, A., Aina, M., Bustaram, I., Risal, Z., Purwanto, Rusdiyanto, \&Tjaraka, H. (2020). Work Ethics of Madura Communities in Salt Business : A Case Study Indonesian. Talent Development and Excellence, 12(1), 3537-3549. http://iratde.com/index.php/jtde/article/view/1312

Hadi Susanto, IndraPrasetyo, TrisaIndrawati, NabilahAliyyah, Rusdiyanto, HeruTjaraka, NawangKalbuana, ArifSyafi'urRochman, G. and Z. (2021). The impacts of earnings volatility, net income and comprehensive income on share Price: Evidence from Indonesia Stock Exchange. Accounting, 7(5), 1009-1016.

Hasoloan, J. (2014). Ekonomi Moneter. Deepublish.

HIDAYAT, W., SOETEDJO, S., TJARAKA, H., SEPTIARINI, D. F., HERLI, M., ULUM, B., SYAFII, M., IRAWAN, H., \& RAHAYU, D. I. (2020). El efecto de la macroeconomía en los precios de lasacciones: estudio de casoindonesio. Revista ESPACIOS, 41(17).

Hidayat, W., Tjaraka, H., Fitrisia, D., Fayanni, Y., Utari, W., Indrawati, M., Susanto, H., Tjahjo, J. D. W., Mufarokhah, N., \& Elan, U. (2020). The Effect of Earning per Share, Debt to Equity Ratio and Return on Assets on Stock Prices: Case Study Indonesian. Academy of Entrepreneurship Journal, 26(2), 1-10.

Huda, N. (2017). Keuangan Publik Islami: Pendekatan Teoritis dan Sejarah. Prenada Media.

Husaini, A., \& Hidayat, N. (2002). Islam Liberal: sejarah, konsepsi, penyimpangan, dan jawabannya. Gema Insani.

Iwata, T. (1996). Characterization of ni-ysz anode degradation for substrate-type solid oxide fuel cells. Journal of the Electrochemical Society, 143(5), 1521.

Jaelani, A. (2018). Sistem anggaran berbasis kinerja pada APBN di Indonesia perspektif ekonomi Islam.

Juanamasta, I. G., Wati, N. M. N., Hendrawati, E., Wahyuni, W., Pramudianti, M., Wisnujati, N. S., Setiawati, A. P., Susetyorini, S., Elan, U., Rusdiyanto, R., Astanto, D., Ulum, B., Khadijah, S. N., Trimarjono, A., Syafii, M., Mubarroq, A., Kristiningsih, K., Pratiwi, R. D., Veri, V., ... Umanailo, M. C. B. (2019). The role of 
customer service through customer relationship management $(\mathrm{Crm})$ to increase customer loyalty and good image. International Journal of Scientific and Technology Research, 8(10).

Kaminska, I., \&Zinna, G. (2020). Official Demand for U.S. Debt: Implications for U.S. Real Rates. Journal of Money, Credit and Banking, 52(2-3), 323-364. https://doi.org/10.1111/jmcb.12660

Kunaifi, A. (2018). TELAAH KRITIS KEBIJAKAN FISKAL PERSPEKTIF KAIDAH FIQH. The 3rd Annual International Conference on Islamic Education, 24-25 Februari 2018, 1-21. http://www.jurnal.stitnualhikmah.ac.id/index.php/proceedings/article/view/255

Lamtiar, S., Arnas, Y., Rusdiyanto, A. A., Kalbuana, N., Prasetyo, B., Kurnianto, B., Saputro, R., Kurniawati, Z., \& Utami, S. (2021). Liquidity Effect, Profitability Leverage to Company Value: A Case Study Indonesia. European Journal of Molecular \& Clinical Medicine, 7(11), 2800-2822.

Lee, K.-S., Divis, P. C. S., Zakaria, S. K., Matusop, A., Julin, R. A., Conway, D. J., Cox-Singh, J., \& Singh, B. (2011). Plasmodium knowlesi: reservoir hosts and tracking the emergence in humans and macaques. PLoSPathog, 7(4), e1002015.

Luck, S., \& Zimmermann, T. (2020). Employment effects of unconventional monetary policy: Evidence from QE. Journal of Financial Economics, 135(3), 678-703. https://doi.org/10.1016/j.jfineco.2019.07.004

Luwihono, A., Suherman, B., Sembiring, D., Rasyid, S., Kalbuana, N., Saputro, R., Prasetyo, B., Taryana, T., Suprihartini, Y., \& Asih, P. (2021). Macroeconomic effect on stock price: Evidence from Indonesia. Accounting, 7(5), 1189-1202.

Ma'mun, M. (2019). PENGARUH PENANGANAN KOMPLAIN TERHADAP KEPUASAN NASABAH DI BANK SYARIAH MANDIRI KCP PRINGSEWU DALAM PERSPEKTIF EKONOMI ISLAM (Studi pada Bank Mandiri Syariah Kantor CabangPringsewu). UIN Raden Intan Lampung.

Manan, H. A., \& SH, S. (2017). Hukum ekonomi syariah: dalam perspektif kewenangan peradilan agama. Prenada Media.

Marios, A., Kalliopi, D., Evangelia, P., \&Paraskevi, P. (2020). Performance Evaluation of Global High-rated ETFs during the Taper Tantrum. Journal of Central Banking Theory and Practice, 9(1), $23-44$. https://doi.org/10.2478/jcbtp-2020-0002

Masoud, S., Bein, M. A., \& Khalifa, W. (2020). Examining the relationship between unconventional monetary policy and exchange rate movements: Empirical evidence from United States quantitative easing. International Journal of Finance and Economics. https://doi.org/10.1002/ijfe.2330

Mayzan, M. B. (2018). Pengaruh Kurs Rupiah, BI Rate, Net Foreign Fund dan Indeks Dow Jones terhadap Indeks Harga Saham Gabungan (Studi Pada Periode Pemberlakuan Quantitative Easing Federal Reserve). UniversitasBrawijaya.

Morgan, P. (2011). Impact of US quantitative easing policy on emerging Asia.

Murdanoto, A. P., Sakai, Y., Sembiring, L., Tani, Y., \& Kato, N. (1997). Ester synthesis by NAD+-dependent dehydrogenation of hemiacetal: production of methyl formate by cells of methylotrophic yeasts. Bioscience, Biotechnology, and Biochemistry, 61(8), 1391-1393.

Murfi, A., Fathurrochman, I., Atika, A., \&Jannana, N. S. (2020). Kepemimpinan sekolah dalam situasi krisis Covid-19 di Indonesia. MANAGERIA: Jurnal Manajemen Pendidikan Islam, 5(1), 119-136.

Pastpipatkul, P., Yamaka, W., Wiboonpongse, A., \&Sriboonchitta, S. (2015). Spillovers of quantitative easing on financial markets of Thailand, Indonesia, and the Philippines. International Symposium on Integrated Uncertainty in Knowledge Modelling and Decision Making, 374-388.

Perillo, C., \&Battiston, S. (2020). Financialization and unconventional monetary policy: a financial-network analysis. Journal of Evolutionary Economics, 30(5), 1385-1428. https://doi.org/10.1007/s00191-020-00698-0

Prabowo, B., Rochmatulaili, E., Rusdiyanto, \&Sulistyowati, E. (2020). Corporate governance and its impact in company's stock price: case study [Gobernabilidadcorporativa y suimpacto en el precio de lasacciones de lasempresas: Estudio de caso]. Utopia y Praxis Latinoamericana, 25(Extra10), 187-196. https://doi.org/10.5281/zenodo.4155459

Rahayu, D. I., Ulum, B., Rusdiyanto, Syafii, M., Pramitasari, D. A., \&Tuharea, F. I. (2020). FUNDAMENTAL IMPACT ON SHARE PRICES: EVIDENCE FROM INDONESIA. PalArch's Journal of Archaeology of Egypt/ Egyptology, 17(6), 9090-9104. https://www.scopus.com/inward/record.uri?eid=2-s2.085099518109\&partnerID=40\&md5=1d2bda9716668cbcb2784e3a9a61df21

Ramin, M. (2020). Sinergitas alumni danpondok pesantren dalam pengembangan kewirausahaan: studi kasus di PondokPesantrenMambaulUlum Bata-Bata danPondokPesantrenDarulUlumBanyuanyarPamekasan Madura. UIN Sunan Ampel Surabaya.

Ramkumar, S., \& Bates, A. (2020). Are long-duration treasuries the best hedge for equities? Journal of Portfolio Management, 47(1), 137-153. https://doi.org/10.3905/JPM.2020.1.182

Risal, T. (2019). Peningkatan peran perbankan syariah dengan menggerakkan sektor riil dalam pembangunan. Accumulated Journal (Accounting and Management Research Edition), 1(1), 36-47.

Rizky, Y. (2015). The Effect of The Fed's Quantitative Easing Policy on the Performance of Listed Companies and the Banking Sector in Indonesia. Australasian Accounting, Business and Finance Journal, 9(4), 71-81. 
Rusdiyanto, Agustia, D., Soetedjo, S., \&Septiarini, D. F. (2020). The effect of cash turnover and receivable turnover on profitability | El efecto de la rotación de efectivo y la rotación de cuentasporcobrar en la rentabilidad. Opcion, 36(Special Ed), 1417-1432.

Rusdiyanto, H. T., Mufarokhah, N., Al'asqolaini, M. Z., Musthofa, A. J., Aji, S., \& Zainab, A. R. (2020). Corporate Social Responsibility Practices in Islamic Studies in Indonesian. Journal of Talent Development and Excellence, 12(1), 3550-3565.

Rusdiyanto, Hidayat, W., Tjaraka, H., Septiarini, D. F., Fayanni, Y., Utari, W., Waras, Indrawati, M., Susanto, H., Tjahjo, J. D. W., Zainal, M., \&Imanawati, Z. (2020). The effect of earning per share, debt to equity ratio and return on assets on stock prices: Case study Indonesian. Academy of Entrepreneurship Journal, 26(2), 110.

Rusdiyanto, \&Narsa, I. M. (2020). The Effect of Company Size , Leverage and Return on Asset on Earnings Management : Case Study Indonesian. Espacios, 41(17), 25.

Rusdiyanto, R., Agustia, D., Soetedjo, S., Septiarini, D. F., Susetyorini, S., Elan, U., Syafii, M., Ulum, B., Suparman, P., \& Rahayu, D. I. (2019). Effects of Sales, Receivables Turnover, and Cash Flow on Liquidity.

Rusdiyanto, R., \&Narsa, I. M. (2019). THE EFFECTS OF EARNIGS VOLATILITY, NET INCOME AND COMPREHENSIVE INCOME ON STOCK PRICES ON BANKING COMPANIES ON THE INDONESIA STOCK EXCHANGE. International Review of Management and Marketing, 9(6). https://doi.org/10.32479/irmm.8640

Rusdiyanto, Sawarjuwono, T., \&Tjaraka, H. (2020). Interpret The Shari ' ah Accounting Practice In Indonesian. Talent Development and Excellence, 12(3), 2420-2433. http://iratde.com/index.php/jtde/article/view/1102

Saputra, T. A., Kunaifi, A., \&Rosyid, A. (2021). Benarkah Kebijakan Fiskal Islam Efektif Menghadapi Resesi? (KontekstualisasiKebijakanFiskalSesuai Shariah). Prosiding Seminar Stiami, 8(1), 1-6. http://ojs.stiami.ac.id/index.php/PS/article/view/1360

Schlepper, K., Hofer, H., Riordan, R., \&Schrimpf, A. (2020). The market microstructure of central bank bond purchases. Journal of Financial and Quantitative Analysis, 55(1), $193-221$. https://doi.org/10.1017/S0022109018001370

Sembiring, M. (2016). Translating TutursiWaloh in Karonese Society into English. Theory and Practice in Language Studies, 6(6), 1142-1148.

Shabbir, M. S., Mahmood, A., Setiawan, R., Nasirin, C., Rusdiyanto, R., Gazali, G., Arshad, M. A., Khan, S., \& Batool, F. (2021). Closed-loop supply chain network design with sustainability and resiliency criteria. Environmental Science and Pollution Research. https://doi.org/10.1007/s11356-021-12980-0

Sihono, T., \& Yusof, R. (2012). Bauran KebijakanMoneter Dan Makroprudensial Bank Indonesia Semenjak Maret 2011 Hingga Maret 2012. Jurnal Economia, 8(1), 97-115.

Simorangkir, I., \&Adamanti, J. (2010). Peran stimulus fiskal dan pelonggaran moneter pada perekonomian Indonesia selama krisis finansial global: Dengan pendekatan Financial Computable General Equilibrium. Buletin Ekonomi Moneter Dan Perbankan, 13(2), 169-192.

Speckesser, S. S., Gonzalez Carreras, F. J., \& Kirchner Sala, L. (2019). Active labour market policies for young people and youth unemployment: An analysis based on aggregate data. International Journal of Manpower, 40(8), 1510-1534. https://doi.org/10.1108/IJM-03-2018-0100

Sumarni, Y. (2020). Manajemen Ekonomi Islam dalamMenanganiPandemi Coronavirus Disease (COVID-19) di Indonesia. Jurnal BAABU AL-ILMI: Ekonomi Dan Perbankan Syariah, 5(1), 117-126.

Susanto, H., Prasetyo, I., Indrawati, T., Aliyyah, N., Rusdiyanto, R., Tjaraka, H., Kalbuana, N., Rochman, A., Gazali, G., \&Zainurrafiqi, Z. (2021). The impacts of earnings volatility, net income and comprehensive income on share Price: Evidence from Indonesia Stock Exchange. Accounting, 7(5), 1009-1016.

Syafii, M., Ulum, B., Rusdiyanto, Suparman, P., Rahayu, D. I., \&Syasindy, N. B. (2020). The effect of financial performance on the company's share price: A case study Indonesian. European Journal of Molecular and Clinical Medicine, 7(8), 1055-1071. https://www.scopus.com/inward/record.uri?eid=2-s2.085098454552\&partnerID=40\&md5=10d4ddcf32dd4bf918ba3622c11e86dd

Taghizadeh-Hesary, F., Yoshino, N., \& Shimizu, S. (2020). The impact of monetary and tax policy on income inequality in Japan. World Economy, 43(10), 2600-2621. https://doi.org/10.1111/twec.12782

Tanaka, A. (2020). Monetary base controllability after an exit from quantitative EASING. Journal of Central Banking Theory and Practice, 9(3), 123-134. https://doi.org/10.2478/jcbtp-2020-0040

Todorov, K. (2020). Quantify the quantitative easing: Impact on bonds and corporate debt issuance. Journal of Financial Economics, 135(2), 340-358. https://doi.org/10.1016/j.jfineco.2019.08.003

Ulum, B., Rusdiyanto, M. S., Rahayu, D. I., \&Pramitasarisari, D. A. (2020). PROFITABILITY IMPACT ON COMPANY SHARE PRICES: A CASE STUDY INDONESIAN. Solid State Technology, 63(6), 1672-1683.

Utari, W., Setiawati, R., Fauzia, N., Hidayat, W., Khadijah, S. N., Pramitasari, D. A., \&Irawan, H. (2020). The Effect of Work Discipline on the Performance of Employees in Compensation Mediation: A Case Study Indonesia. 17(9), 1056-1073. 
Ward, M. (2020). Making money for COVID-19. Emerald Emerging Markets Case Studies, 10(3), 1-9. https://doi.org/10.1108/EEMCS-05-2020-0154

Wentrup, R., Nakamura, H. R., \&Ström, P. (2019). Uberization in Paris - the issue of trust between a digital platform and digital workers. Critical Perspectives on International Business, 15(1), 20-41. https://doi.org/10.1108/cpoib-03-2018-0033

Whalen, C. J. (2019). Schools of thought and theories of the state: Reflections of an institutional economist. In The Stratified State: Radical Institutionalist Theories of Participation and Duality: Radical Institutionalist Theories of Participation and Duality. https://doi.org/10.4324/9781315487090-4

Yang, Z., Zhou, Y., \& Cheng, X. (2020). Systemic risk in global volatility spillover networks: Evidence from option-implied volatility indices. Journal of Futures Markets, 40(3), 392-409. https://doi.org/10.1002/fut.22078

Zabala, J. A., \& Prats, M. A. (2020). The unconventional monetary policy of the European Central Bank: Effectiveness and transmission analysis. World Economy, 43(3), 794-809. https://doi.org/10.1111/twec. 12880

Zainudin, M. (2015). Analisis penanganan pembiayaan murabahah bermasalah di BMT Surya Sekawan Mandiri dalam perspektif ekonomi Islam. UIN Walisongo.

Zainurrafiqi, Gazali, N. Q. and N. H. (2020). The Effect Of Organization Learning Capability And Organizational Innovation On Competitive Advantage And Business Performance. Russian Journal of Agricultural and Socio-Economic Sciences (RJOAS), 3(99), 9-17. https://doi.org/10.18551/rjoas.2020-03.02

Zainurrafiqi , RiaRacawati, Devi Lestari PramitaPutri , EnzaResdiana , EndangWidyastuti , QaiyimAsy'ari , Rusdiyanto, W. H. (2020). The Determinants And Consequents Of Competitive Advantage Based Of Local Wisdom At The Micro, Small, And Medium Enterprise : Evidence From Indonesia. Solid State Technology, 63(6), 1604-1620. 